Enersyds is dit 'n voorreg om 'n paar opmerkings oor Van Huyssteen se artikel te maak, omdat dit op 'n skerpsinnige wyse ' $n$ bepaalde probleem in die teologie blootlê wat inderdaad van die allergrootste belang is, en ook in Suid-Afrika tans in die teologiese wandelgange druk bespreek word.

Andersyds is dit met huiwering dat ek - na aanvanklike protes - tog die redaksie van Koers se uitnodiging aanvaar het om 'n paar opmerkings te maak ten einde 'n diskussie oor die saak te stimuleer. My huiwering spruit daaruit voort dat dit nie my spesialisasieterrein in die teologie is waarop ek my nou begewe nie, en dat dit juis die gebied is waarop Van Huyssteen gedurende die laaste jare gekonsentreer het. Dié gebied sou ons kon noem die metateologie of die teorie van die teologie of die fundamentele teologie (die Fundamental-theologie). Dit gaan in dié teologiese gebied om die agtergrond van die teologie, die fondamente, metode of waarheid - om maar 'n paar fasette te noem. Ebeling sê dit kom hier ten slotte neer op die vraag na die waarheid van die teologie, en gevolglik na die verifikasieproses waardeur die waarheid van teologiese uitsprake bevestig of ontken kan word 1 ).

Die doel van my paar opmerkings is nie om werklik 'n nuwe bydrae tot die probleemgebied te lewer nie, maar om te kyk na die bydrae wat Van Huyssteen lewer. Hy verdeel sy artikel in vyf punte, en ek sal iets oor elke punt sê onder die ooreenstemmende vyf punte. Daarna volg niks meer nie as 'n kort skets oor my siening van die probleem.

1) G. Ebeling: Studium der Theologie - Eine enzyhlopödische Orientierung, Tübingen, 1975, p. 164. 
1. As opskrif bo hierdie eerste punt in Van Huyssteen se artikel sou 'n mens dalk kon skryf: „Probleemstelling - die noodsaak van 'n teologiese metateorie". Van Huyssteen stel hier die vraag of teologie 'n wetenskap is. Om met reg op wetenskaplikheid aanspraak te maak, vereis 'n spesifieke teologiese kenwyse (of metode) „wat óók aan die eise van die hedendaagse wetenskapsteorie sal voldoen". As minimum vir hierdie wetenskapsteorie stel hy „die eis dat geen wetenskaplike uitspraak of aanspraak ongetoets veronderstel $k$ an word nie, maar op een of ander wyse betroubaar gekontroleer moet word".

Hiermee verwerp Van Huyssteen in beginsel die ,besonder eksklusiewe waarheidsaanspraak" wat gewoonlik vir die teologie opgeëis word. Hierdie aanspraak lui gewoonlik dat die studieveld van die teologie - die openbaring van God - eenroudig waar is en dat die teologie hieroor ware uitsprake kan maak indien dié uitsprake ooreenkom met die inhoud van die Bybel. Van Huyssteen ervaar hierdie soort ongekontroleerde aanspraak as 'n beslissing wat die wetenskaplikheid van die teologie verlore laat gaan en van teologie 'n blote geloofsleer maak, dit wil sê 'n ontleding van die dinge wat ' $n$ bepaalde groep mense inderdaad glo. Onder punt 5 sal ek egter aan Van Huyssteen vra in watter mate hy self aan hierdie ongekontroleerde beslissing ontkom.

2 en 3. As opskrif bokant hierdie tweede punt in Van Huyssteen se artikel sou 'n mens kon skryf: ,'n Analise ran Her'ns en Jonker". Hy begin veral by Jonker se siening van teologie as Skrifteologie, Skrifuitleg, 'n diens aan die juiste vertolking van die evangelie. Weens die geweldige rol wat die gesag van die Skrif hier speel, word 'n finale fundering van teologiese uitsprake onmoontlik en deel die teologie in die onbewysbaarheid van die Christelike geloof self. Die teologie is eenvoudig andersoortig en uniek ten opsigte van die ander wetenskappe.

Nogtans wil nòg Jonker, nòg Heyns die wetenskaplikheid van die teologie prysgee. Veral Heyns lê egter soveel klem op die teologie as 'n eiesoortige wetenskap met 'n eie karakter en eic tipe rasionaliteit, dat hy in laaste instansie self nie ontkom aan die drastiese isolasie van die teologie waarvan hy Barth beskuldig nie.

Ek meen dat Van Huyssteen hierin gelyk het. Heyns ontwik- 
kel enersyds 'n besondere breë en omvattende wetenskapsleer waarbinne hy die teologie 'n plek wil gee, maar daar word uiteindelik soveel beperkinge en kwalifikasies op die wetenskaplike karakter van die teologie geplaas (onder andere 'n paradoksale, dialektiese en analogiese in plaas van logiese denkvorm) dat 'n mens moeilik kan insien hoe die teologie nog tuis kan wees binne die kader van die algemene wetenskapsteorie.

4. As opskrif sou mens by hierdie punt in Van Huyssteen se artikel kon gebruik: „Heyns het dieselfde probleem as Barth”. Onder hierdie punt analiseer Van Huyssteen Barth se siening van teologie as ' $n$ wetenskap. Hy toon aan dat daar twee redes is waarom die teologie by Barth uiteindelik geisoleer word van die ander wetenskappe. Die eerste is Barth se gereduseerde openbaringsbegrip (waarop Heyns ook reeds gewys het) en die tweede is dat Barth nie daarin slaag om oortuigend aan te toon dat hy inderdaad by God en sy openbaring begin nie. Van Huyssteen meen dat Barth in werklikheid by 'n hoogs subjektiewe voorstelling oor God en sy openbaring begin en daarmee die teologie buite die kader van die moderne wetenskapsleer plaas. Op hierdie stadium wys Van Huyssteen prinsipieel die moontlikheid af om onbemiddeld by God en sy openbaring te begin aangesien $\mathrm{Hy}$ vandag vir ons slegs deur 'n akte van interpretasie toeganklik is. Ook Heyns noem teologie ,'n waagstuk van die geloof" en Van Huysstecn sien hierin net so 'n drastiese isolering van die teologie as by Barth.

Hier sou ek graag 'n paar kleiner vrae aan Van Huyssteen wou vra. Op bladsy 389 stel hy prinsipieel dat daar geen onbemiddelde toegang is tot God en sy openbaring nie, maar slegs deur 'n daad (akte) van interpretasie. Maar in die laaste sin van punt 4 beweer Van Huyssteen dat Heyns se teologiese konsepsie om bepaalde redes uiters problematies word en dat dit by Heyns „dan feitlik onmoontlik word om vas te stel of teologiese uitsprake werklik God en sy openbaring uitspreek, òf eerder menslike oortuigings óór God en sy openbaring". Ek meen hierdie twee stand. punte rym nie omdat die prinsipiële onmoontlikheid in die laaste geval skynbaar plek maak vir 'n prinsipiäle moontlikheid wat net in die ,geval Heyns" erg moeilik is. 
5. As opskrif sou kon dien: „Van Huyssteen se eie standpunt”. Met hierdie punt het ek die meeste probleme, omdat ek meen dat Van Huyssteen eenvoudig te $\min$ sê om sy eie standpunt duidelik te maak, en omdat sommige van sy uitsprake die indruk skep dat hy self eenvoudig bepaalde basiese uitgangspunte outoritêr poneer.

Veral van die derde paragraaf onder punt 5 af, begin Van Huyssteen die diepste rede gee waarom hy oortuig is dat teologie inderdaad 'n wetenskap is en as wetenskap aan die eis van die gangbare wetenskapsteorie moet beantwoord. Sy argument is dat dit teen die wese van die teologie is om in afsondering bedry $f$ te word „omdat die universaliteit wesenlik met die Godsgedagte gegee is", en ,in die teologie gaan dit inderdaad om God en sy openbaring". Daarom is die omskrywing van teologie as Skrifteologie en Skrifuitleg (Jonker) eenvoudig te min gesê; want wie die Skrif wil uitlê, moet in elk geval praat ,oor die skepping van die wêreld, van mense, en van die geskiedenis Gods met hierdie mensheid - 'n geskiedenis wat alle gebeure vanaf die begin tot aan die toekomstige einde omspan". Die universaliteit van die teologie grond dus in die monoteistiese Godsgedagte.

Ek dink die vraag lê voor die hand. As dit waar is dat die Godsgedagte universalisties is (in die sin waarin Van Huyssteen van sy wesenlike universaliteit praat), is Van Huyssteen natuurlik volkome korrek, dan kan die teologie nie geïsoleerd bedryf word nie. Maar wie sê die Godsgedagte is universalisties, en wie sê hierdie Godsgedagte is ' $n$ ware, korrekte gedagte oor die ware God? Barth het minstens nog poneer dat hy oor die ware God praat en sy teologie by Hom begin, maar Van Huyssteen begin uit die staanspoor met 'n Godsgedagte sonder enige teoretiese verantwoording dat dit wat hy poneer (onder meer die Godsgedagte én die universaliteit daarvan), waar is of selfs net kontroleerbaar is.

Nou bestaan die moontlikheid egter dat ek Van Huyssteen op hierdie punt in werklikheid verkeerd begryp. Immers dit kan wees dat hy juis prinsipieel afsien van die moontlikheid om enige wetenskaplike karakter vir die teologie op te eis via die kontro- 
leerbaarheid van sy teologiese vertrekpunt, en dat dit dus vir hom volkome onbelangrik word of 'n mens as teologiese vertrekpunt 'n direkte toegang tot God poneer -- wat agteraf blyk 'n verbloemde, subjektiewe Godsgedagte (interpretasie van God) te wees, en of jy dit eenvoudig van die begin af duidelik stel dat jy uitgaan van 'n Godsgedagte (wat dan seker ook 'n subjek tiewe interpretasie van God is), omdat jy die wetenskaplike karakter van die teologie anders sien. Dit mag Van Huyssteen se standpunt wees in die lig van die laaste twee sinne vorr dic finale 10 punte begin. Hier stel hy dat die aird van die boodskap van dic Bybcl as eskatologiese boodskap - „tenlogicse uitsprake noodwendig onaf, voorlopig en hipotcties" maak. ,Juis as gevolg van die eskatologiese spanning tussen Gods openbaring en ons geskiedenis, moet die teoloog metodies tot begrensde uitsprake bereid wees".

Die vraag is egter wat dan van die wetenskaplike karakter van die teologic word. Sal die aard van teologiese uitsprake soos nog eens beskry $[$ onder punt 3 van die laaste 10 punte, voldoen aan die eise van dic hedendaagse wetenskapsteorie? Immers volgens genoemde punt 3 impliscer teologiese uitsprake ,een of ander vorm van kontrole of toetsing, wat egter nie beteken dat vooraf sonder meer op een bepaalde vorm van kontrole besluit word, ò dat alle teologiese uitsprake uiteindelik wél kontroleerbaar is nie" (my kursivering). Dic vraag is of dié karaktcrisering van teologie nog die cise van die hedendaagse wetenskapsteoric sal kan bevredig, en of Van Huyssteen nic hiermee nóg 'n teoloog word in dieselfde ry as Barth en Heyns, wat so ' $n$ uitsonderlike karakter ain die teologie toeken dat dit nic meer met oortuiging sy wctenskaplikheid kan handhaaf nie. 'n Paar uitsprake van Van Huyssteen onder punt 5 skep nogal so 'n indruk van ongekontroleerdheid en selfs onkontrolecrbaarhcid. Die tweede laaste paragraaf van punt 5 begin met: „V $\mathrm{V}_{11}$ in Christelike tcologic is daar uiteindelik slegs één vertrekpunt, en dit is die Skril sclГ". Die laaste sin in punt 5 (van die laaste 10 punte): „Dic Skrif het gesag omdat dit ons na die Christusgebeurc lei...". Ek het die „omdal” gekursiveer omdat ek geen grond daarvour vind in Van Huyssteen se beredenering nie.

Ek wil egter die moontlikheid ooplaat dat ek ook met hicrdie 
poging om Van Huyssteen te interpretecr, misgetas het. Maar dan sou hierdie reaksie op sy artikel minstens dié voordeel hê dat hy dan weet hoe hy misverstaan kan word, en dalk daarop kan reageer met 'n paar verhelderende opmerkings.

\section{My siening}

Laat ek kortliks probeer om positief iets te sê. Miskien is dit die beste om by 'n absolute minimum te begin, waaroor die meeste teoloë - en ander wetenskaplikes - seker sal kan saamstem.

As minimum wil ek stel dat teologie die wetenskap is wat die Christelike tradisie bestudeer. As studie-objek kom dan inderdaad die Bybel ter sprake (waaraan in bepaalde teologiese dissiplines inderdaad dic meeste tyd bestee word), maar daarbenewens ook die ganse Christelike tradisie, vóór en ná die Bybel. Onder ,vóór" verstaan ek die geskiedenis wat aan die opskrifstelling van die Bybelse boeke voorafgegaan het, dus die geskiedenis waarin God Hom volgens die Bybel geopenbaar het, en waarvan daar geskryf word in die Bybel. En onder "ná" verstaan ek die geskiedenis van die Christendom. Dat teologie in hierdie sin 'n wetenskap is, of liewer 'n aantal wetenskappe, behoef seker min betoog. Dit is tog presies dieselfde situasie met Hebreeus en Grieks, en 'n hele boel ander literatuurwetensk appe wat minstens onder andere dokumente ondersoek en tot betroubare, kontroleerbare resultate kom. In dié sin kan 'n mens 'n studie maak van die God van Israel. Daarvoor het jy die dokumente (in hierdie geval minstens die Ou Testament) tot jou beskikking. Volgens erkende maatstawwe van literêre ondersoek kan die dokumente nagevors word, en die resultate opgeteken en gekontroleer word. Dit sou byvoorbeeld moontlik wees om te bepaal dat so 'n ondersoek 'n bepaalde deel van sy studieveld, sê nou maar DeuteroJesaja, sleg ondersoek het en dus bepaalde gebrekkige of foutiewe resultate in sy geheelbeeld van Israel se God ingebou het. Sover lyk dit my egter 'n duidelike saak. Teologie is alreeds in dié minimale $\sin$ 'n wetenskap wat volle reg het om op universiteit gedoseer te word. Die vrees dat teologie dalk van die universiteit 
geweer kan word, is een van Van Huyssteen se belangrikste beweegredes om oor die wetenskaplikheid van teologie te besin.

Tog sal 'n mens moet erken dat teologie as ,wetenskap van die Christelike tradisie", minder is as wat normaalweg daaronder verstaan word. Tradisioneel gaan dit in die teologie natuurlik wel om die Christelike tradisie en om literatuurstudie, maar tog ook om méér - en veral om die laaste, basiese waarheidsuraag.

Die vraag is naamlik of dit wat die Bybel sê oor die God van Israel of oor Jesus Christus waar is. Het God Israel uit Egipte uitgelei, het $\mathrm{Hy}$ hemel en aarde geskape, het $\mathrm{Hy}$ Jesus opgewek uit die dood, sal Jesus weer kom? Hierop het Barth eenvoudig geantwoord: Dit is so, God het so gesê. Maar is hierdie uitspraak nou toeganklik vir algemene wetenskaplike verifikasie?

Die antwoord op hierdie vraag is van eksistensiële belang vir elke mens. Dit is van die allergrootste betekenis of die Bybelse boodskap waar of vals is. Immers dié boodskap beweer geweldige en beslissende dinge oor die werklikheid waarin ons leef: of God bestaan of nie, of Israel se God dié enigste ware God is of nie, of Jesus Christus die besondere openbaring van dié God op aarde is of nie, of Jesus Christus uit die dood opgestaan het of nie, is van beslissende betekenis. Indien hierdie boodskap van die Bybel waar is, gee dit ' $n$ finale stempel aan die ganse werklikheid en aan die betekenis van elke mens se lewe. En dan sal die teologie dié waarheid en die implikasies vir ons lewens- en wêreldbeskouinge moet deurdink.

Ons staan hier egter voor grensvrae, vrae wat nie finaal geverifieer of gefalsifieer kan word nie (Van Huyssteen punt 10) omdat ons nie oor metodes beskik om dit te doen nie en (of?) omdat die geskiedenis nog onaf is, en die waarheid van dié aansprake van Israel se God eers uit die afloop van die geskiedenis kan (sal?) blyk.

Dit laat ons egter nie in 'n radikale voorlopigheid vassteek nie. Die Bybel verhaal 'n groot stuk geskiedenis wat wel prinsipieel kontroleerbaar is - al is dit ook hoe moeilik weens ons afstand van die Bybelse verhale én die afstand tussen dié geskiedenis en die opskrifstelling van die Bybelse verhale. (Vergelyk Van Huyssteen se twee "hermeneutiese distansies" wat oorbrug moet 
word. Ek meen egter hy heg te veel prinsipiële betekenis hieraan. Dit is praktiese probleme). Die taak van die teologie is om hierdie kontrole so ver monntlik uit te voer deur te vra na tekens van betroubaarheid in dic Bybelse verhalc. Is daar byvoorbeeld rede om te aanvaar dat daar wel 'n uittog was en dat dit onder die leiding van 'n god plaasgevind het $\mathrm{cn}$ dat hierdie god die een is wat later as Israel se God bekend gestaan het? Is daar rede om die getuies van Jesus sc opstanding te glo? Is daar rede om Paulus se interpretasie van dié gebeurtenis te vertrou? Op sommige vrae sal moontlik inakliker antwoorde gekry kan word as op ander, maar daar is nie op elke vraag 'n antwoord nodig voordat 'n atmosfeer van vertroue in die geloofwaardigheid van hierdie stuk literatuur (die Bybel) geskep word nie. Hierdie atmosfeer is egter vir die verkondiging van dié boodskap van die allergrootste belang.

En om ten slotte by die teologie as universitêre dissipline(-s) terug te kom: hierdie vertroue lê ten grondslag van die feit dat die teologiese dissiplines wel in ' $n$ aparte teologiese fakulteit georganiseer is, en nie eenvoudig as dissiplines in die Letterefakulteit gedoseer word - soos byvoorbeeld met Godsdienswetenskap soms wel gedoen word nie. 